\title{
金沢工業高等専門学校機械工学科における エンジニアリングデザイン教育の取り組み
}

Development of Engineering Design Education in the Department of Mechanical Engineering at Kanazawa Technical College

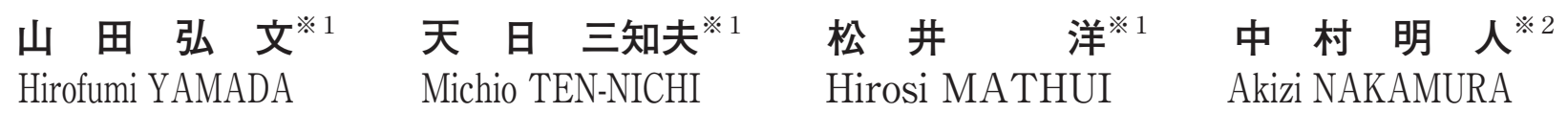

This paper introduces a method of the engineering design education for college of technology mechanical engineering students. In order to teach the practical engineering design, the MILSTD-499A process is adapted and improved upon for a Mechatronics hands-on lesson used as the MOT method. The educational results in five years indicate that knowledge of the engineering management is useful for college students in learning engineering design. Portfolio for lessons and the hypothesis method also have better effects on the understanding of the engineering specialty.

Keywords : Engineering Design, Hands-on, Management, Team Work, Mechatronics キーワード：エンジニアリングデザイン，モノづくり，管理，チームワーク，メカトロニクス

1.はじめに

技術の高度化が加速され，多機能で高性能な工業製 品が，社会生活に利便を供するようになった．危機的 に叫ばれた若者の理科離れの傾向も，SPP，STPなど 各種の文教政策によって徐々に沈静化しつつあるもの の, 一方では，若手技術者の創造性や工学設計（Engineering Design）能力の欠如が危惧されている.

このような問題を解決するために，デジタルエン ジニアリングの活用, MOT (management of design process based on engineering technology）およびエ ンジニアリングデザイン等に立脚した初級技術者育成 教育の必要性が提唱され始めている ${ }^{11}$.

金沢工業高等専門学校（以下金沢高専）では，創設 以来，「実践的技術者の育成」を教育の目標に，もの づくりを中心とした教育を実施してきた。1997年以降 は総括的な教育目標に人間形成要素を高めて,「ここ ろゆたかで，創造性にあふれた技術者の育成」とし， 各専門学科がこれを具体化する，「実学志向のものづ くり教育」を進めてきた ${ }^{2)}$.

機械工学科においては，ものづくりの全般過程を認 識し技術の目利きが出来る，「メカトロニクスに強い実 践的初級技術者の育成」を具体的目標としてきた。こ れを，MIL-STD-499A（米空軍規格：廃版）に準拠し たエンジニアリングマネジメントの概念 ${ }^{3)}$ と, 筆者ら が実業界で得たものづくり経験をもとに構築した，高

平成 20 年 2 月 8 日受付

※ 1 金沢工業高等専門学校

※2VRテクノセンター
専 5 年間を通じた積み上げ式の「創造実験」体系にも とづいた教育で実現してきた，第 4 学年におけるメカ トロニクスものづくりを頂点とした当該教育における 学生の満足度（後掲, 図 4) 並びに, 卒業後に回顧し た当該教育に対する卒業生の満足度（訪問者への聞き 取り）はいずれも高く，一連の教育の仕組みが機械工 学科のものづくり教育として妥当であると判断する.

本報告では,「Engineering Design」を包括的に捉え， 従来の教育成果とこれに企業技術者の参画及び，米国 大学等に扔けるEngineering Design教育現地調査の結 果を加味し, 新たに試行中の金沢高専機械工学科にお ける実践的技術者教育について報告する。

\section{2. 機械工学科の実践的初級技術者像と教育方法}

2.1 卒業生の状況と技術者像の変化

図 1 は, 2007年度の卒業生の進路を示している。就 職者の約 7 割は, 北陸地区（特に石川県）における企 業に就職し, 将来の幹部要員とされる傾向にある。 ま た，地元産業に就職し熟年期にある卒業生の多くは,

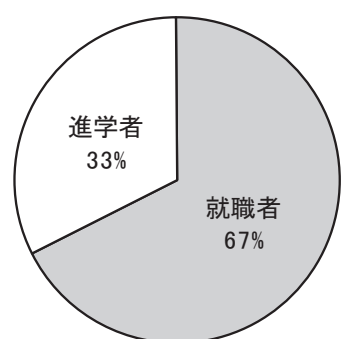

図 1 2007年度における金沢高専卒業生の進路概要 
表 1 機械工学科の初級技術者の技術的主要資質

\begin{tabular}{|c|c|c|}
\hline 区 分 & 概 & 実現方法等 \\
\hline 倫 理 観 & 高い技術者倫理観, 常識 & 技術者倫理科目 \\
\hline 経 営 観 & $\begin{array}{l}\text { 技術・製品開発管理の } \\
\text { 基礎 } \\
\text { 企業構成員感覚, 経済 } \\
\text { 感覚 }\end{array}$ & $\begin{array}{l}\text { MIL-STD-499Aの適用 } \\
\text { 想定方式, Roll Play }\end{array}$ \\
\hline 社 会 性 & 顧客感覚, 協働能力 & グループ活動 \\
\hline 専門知識 & $\begin{array}{l}\text { メカトロニクス, 機械 } \\
\text { 設計技術者 } 3 \text { 級程度 }\end{array}$ & $\begin{array}{l}\text { 講 義, 実習, 演習, } \\
\text { 審査会議, プレゼン }\end{array}$ \\
\hline 専門技能 & 機械加工技能 & 加工ライセンス取得 \\
\hline $\begin{array}{l}\text { 基礎能力 } \\
\text { と自主性 }\end{array}$ & $\begin{array}{l}\text { 記述, 読解, 計算力, } \\
\text { 分析力, 問題解決力 }\end{array}$ & $\begin{array}{l}\text { 演習, ポートフォリ } \\
\text { オ他（創 IV）とキャ } \\
\text { リアデザイン連接 }\end{array}$ \\
\hline
\end{tabular}

地域企業の起業家や管理者として地域社会に貢献して いるものが多い．同様に在校生の中には地域企業家の 師弟も多い，加えて，90年代からはUターン現象が目 立つようになってきた。

このような学生及び卒業生の傾向に鑑み, 1996年の 教育改革では教育目標を「こころゆたかで, 創造性に あふれた技術者の育成」とし，ものづくりは人づくり の合言葉の下に，ものづくりを中心とした教育実践に 努めて来た，その際，機械工学科においては，地元企 業のOJT実施の可能性と実績を考慮し, 将来卒業生が 地域企業の管理者的立場になりうる創造的初級技術者 像のうち，技術的傾面の具備すべき資質として，表 1 の主要資質を採り上げることとした.

経営感覚については, 初級技術者もものづくりの全 過程を認識しスタッフとして並行的・先行的・自主的 に業務を進めることが必要であることを要求している. また，想定方式やロールプレイ教育では企業の各役職 が念頭に置かなければならない，危機管理や着意事項 (価格, 納期等) を擬似経験することを意味している.

社会性については，企業内構成員として，あるいは プロジェクト構成員として協働参画するためのコミュ ニケーション能力や, 顧客優先の社会感覚を体得する 必要があることを意味している。

専門知識については，機械設計技術者 3 級程度の知 識を持ち，企画や会議への参画及びプレゼンテーショ ン能力があれば，初級技術者の職務遂行には無難であ ることを狙っている.

専門技能については，機械加工技能（一部はNC加 工を含む）が必要で，知識のほか指定したライセンス を取得し，自ら加工できることを要求している.

基礎力と自主性では，近年初級技術者の能力低下が 危惧されている項目について，5年間の創造実験教育 細目を通して着意すると共に，4学年の創造実験細目 （創造実験IV）においてポートフォリオ作成を義務づけ, 新たな修得知識・教訓・ノウハウのデータ化の方法を 学ぶほか，これを自らのキャリアデザインへの取り込み につなげる必要性を根付かせることを目的としている.
表 2 機械工学科のものづくり教育体系の経緯概要

\begin{tabular}{|c|c|c|l|}
\hline 期 & 年 代 & \multicolumn{1}{|c|}{ 育成目標 } & \multicolumn{1}{|c|}{ 概 要 } \\
\hline 1 & $\sim 1980$ & 実践的中堅技術者 & $\begin{array}{l}\text { 機械加工実習, 万力 } \\
\text { 製作他 }\end{array}$ \\
\hline 2 & $1981 \sim$ & 問題提起解決志向 & $\begin{array}{l}\text { 機械加工実習, ギヤ } \\
\text { ボックス }\end{array}$ \\
\hline 3 & $1996 \sim$ & 問題提起創造型 & $\begin{array}{l}\text { 加工, メカトロ主体, } \\
\text { MIL-STD }\end{array}$ \\
\hline 4 & $2007 \sim$ & 創造型実践技術者 & $\begin{array}{l}\text { 加工, メカトロ一貫, } \\
\text { MIL-STD }\end{array}$ \\
\hline
\end{tabular}

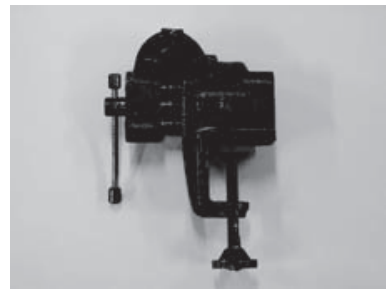

(a) 第 1 期（万力）

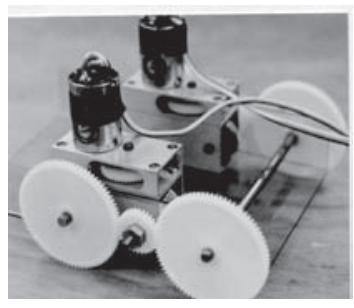

(b) 第 2 期（サッカーロボット）

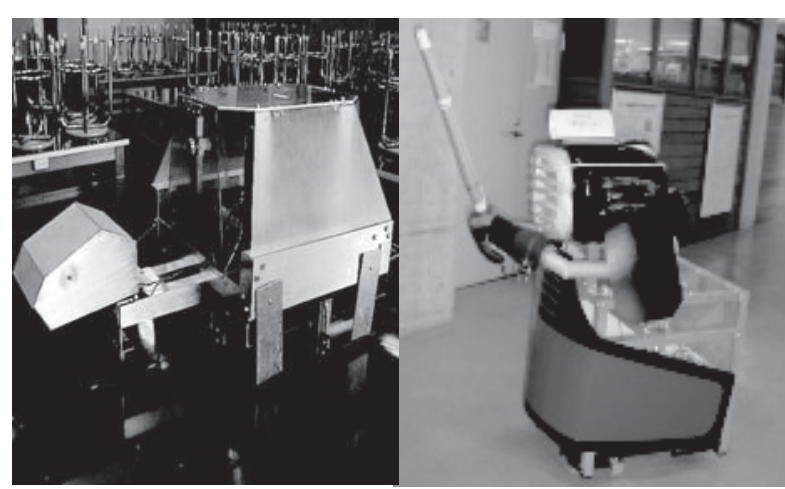

(c) 第 3 期成果物（校内案内ロボット例）

図 2 ものづくり学生製作成果物の例（創造実験 $\mathrm{IV}$ )

\section{2 機械工学科のものづくり教育体系の変遷}

表 2 は, 機械工学科のものづくり教育体系の変遷経 緯とその概要を, 図 2 は成果物の例を示している.

第 1 期は, 設計及び加工技能を重視した時期である. 1 学年から 4 学年までのもの作り教育 (各学年約 $4 \mathrm{~h}$ ) を通じ，鋳造〜機械加工〜仕上げ加工までを体験でき ることにした，最終的には，図 2 (a) の万力を個人で 仕上げることを目標とした。

第 2 期は，設計製作の時代で，加工技能の向上も図 りつつ, 4 年次には製品を活用し有線操縦のサッカー ロボット（図 $2(\mathrm{~b}))$ を 2 人 1 組で製作した.

第 3 期は，初期のエンジニアリングデザイン思想を 考慮した教育体系の時代で, ものづくりの流れを中心 とした実務型教育を構築した．即ち，ものづくりにお ける顧客, 雇用者, 製作管理者及び製作者の果たすべ き役割を時系列的に捉えて, ものづくりの目的を達成 することを重視し，これを演習と創作活動の組み合わ せによって実現する方法である。

このため, 顧客要求分析に始まるものづくりの全過 程を通じた諸業務を, 筆者ら（山田, 中村）が実業 
界で準用したMIL-STD-499A Engineering Management ${ }^{3)}$ 手法 (米空軍研究開発管理手法. 現在は廃版. 内容: 研究開発において納期と品質を保証するため, 必要な工学的活動に関して顧客サイドと製作・技術サ イドが実施しなければならない事項に関する規定等) を，金沢高専の実情に合わせて修正し適用することと した．同時に，一般的になったメカトロニクスを主題 とし， 2 学年後半〜 4 学年までのもの作り教育を一貫 したテーマで積み上げ式に実施することを試み, 図 3 に示すものづくり教育体系を確立した.

1 及び 2 学年前半の工学共通細目は, ものづくりの 動機付けを目的とし，全学科に共通する物理的実験を 内容とした， 2 学年後半の機械基礎は，製図及び加工 技能の習得である. 3 学年は, 機構, 制御・信号処 理, 動力・電源・センサのメカトロニクスの基礎を, 実習と製作を通じて履修する。4 学年の創造実験 $\mathrm{IV}$ MIL-STD-499Aの手法を準用したメカトロニクスも のづくりの仕上げとし, 自由な発想で「校内案内ロボッ 卜」（図 $2(\mathrm{c}))$ をグループで製作した.

MOT手法の準用よりも，MIL-STD-499Aの手法を 準用した理由は，(1)高専教育では，MOTにかかわる 技術的根拠を与える理論教育を実施する時間が不足す ること. (2)就職する対象企業(主として地域中小企業) における技術が，理論よりもノウハウに支えられてい ること. (3)就職対象企業では技術者の兼業が常態であ ること等である.

第 3 期におけるものづくり教育は, 全学年に亘り, 学生間に好感を持って受け入れられた。図 4 は, 第 3

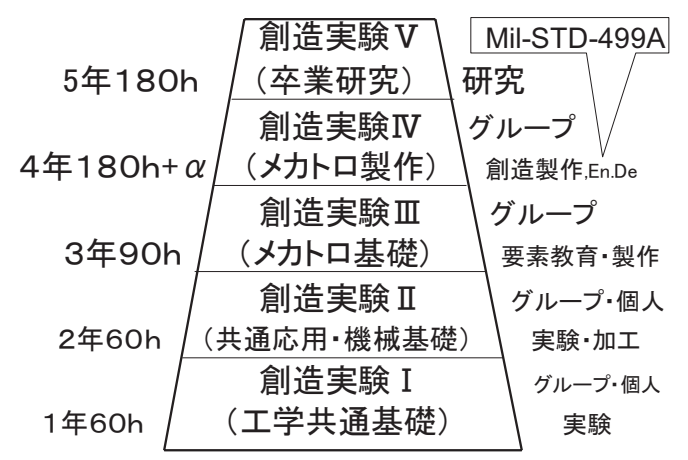

図 3 ものづくり教育体系（1996～2006）

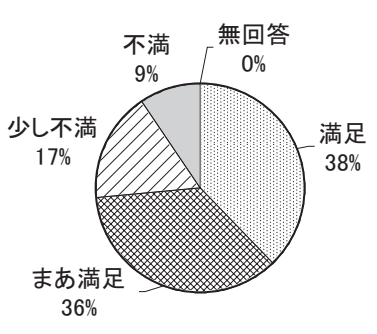

平成18年度満足度詳細

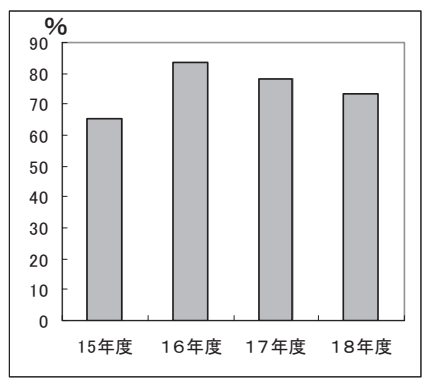

4 年間の満足度比較
図 4 創造実験IVに関する学生授業アンケート結果
期の創造実験 IV に関する, 学生の授業アンケート結果 を示している．授業時間に加え多くの課外時間の投入 を必要とし, 学生にとっては負担となっているものの 満足度（満足とまあ満足の合計）が高い.

\section{3. 機械工学科における第 4 期ものづくり教育体系} 第 4 期は, 表 1 の項目をより身近なものとすること, 地域連携教育との連接を図ること, 学生のキャリアデ ザインの教育成果との連接を加速すること, 技術者倫 理を加えることを企図した．同時に，ものづくり技術 の趨勢へ対応しメカトロニクス技術レベルの向上を図 ること，ものづくり教育体系を改善すること等も目的 としている，また，学生の育成目標を「ものづくりの 過程を通じ, 技術の目利きが出来る実践的技術者の素 養を育成する」として, 時代へ対応できる初級技術者 像を描いた。

\section{1 ものづくり教育技術の趨勢調查と教訓の活用} ものづくり教育の趨勢を予測するため，2006年末， 米国大学等の教育事情（表 3 ）を実地調査し, 今後の 改善資料を収集した。 その結果, 僅か 3 校の調査結果 ではあるが, 各大学等で地域企業との連携及び実用品, あるいはプロトタイプ品のものづくり教育が行われて いることが特徴であった。 また, 学科横断型（総合型） 共同研究及びデジタルシミュレーションを多用したも のづくりが奨励されていた（Mat. Lab., World Bridge Contestなど)。このような事実は, 既説の通り ${ }^{1)}$, 米 国に抒けるものづくり教育が「実学志向」で，グルー プ活動を原則としていることを裏付けている. 同時に, 当該教育従事者等は，この傾向は今後も継続すると明 言していた.

ところで，筆者等の内の 2 名が実業界におけるもの づくり経験で得た多くの教訓は, 図 5 の総合化の必要 性, 及び, 初級技術者が必須と思われた事項（表 1) に大別される. 図 5 は，筆者らの実務経験を基に表し ているが, 今後のものづくりは個人の技術力では対応 が難しくなることを意味している，実際，製品が 1 世 代進むごとに性能は1.3〜 2 倍, 費用効果は $1.2 \sim 1.5$ 倍程度の向上が見られるという市場の実態 ${ }^{2)}$ は, 初

表 3 米国大学等におけるものづくり教育調查概要

\begin{tabular}{|c|c|c|}
\hline $\begin{array}{c}\text { 調査大学等 } \\
\text { (所在地) }\end{array}$ & $\begin{array}{l}\text { 特徵 } \\
\text { その他 }\end{array}$ & $\begin{array}{c}\text { エンジニアリングデザイン教育 } \\
\text { の概要と特記事項 }\end{array}$ \\
\hline $\begin{array}{l}\text { Olin大学(私) } \\
\text { (MA.) }\end{array}$ & $\begin{array}{l}\text { 新設, も } \\
\text { のづくり } \\
\text { 産学連携 }\end{array}$ & $\begin{array}{l}\text { ·学科横断型物づくり. H.M.C.型 } \\
\text { ·理論と実践 (自立型教育) } \\
\text { · 産学共同型卒業研究 (総合型) }\end{array}$ \\
\hline $\begin{array}{l}\text { 陸軍士官学 } \\
\text { 校 (NY.) }\end{array}$ & $\begin{array}{l}\text { 物づくり } \\
\text { 発祥校 } \\
\text { 実用品製作 } \\
\text { ブリッジン }\end{array}$ & $\begin{array}{c}\text { ・ MIL-STD-499-A型物づくり } \\
\text { ・ユーザ共同型学科横断型卒業研 } \\
\text { 究, コミュニケーション重視 }\end{array}$ \\
\hline $\begin{array}{l}\text { F.D.NY州 } \\
\text { 立大 }(\mathrm{NY})\end{array}$ & $\begin{array}{l}\text { 物づくり } \\
\text { 地域連携 }\end{array}$ & $\begin{array}{l}\cdot \text { 学科単独型卒業研究 } \\
\cdot \text { 地域貢献型連携物づくり教育 }\end{array}$ \\
\hline
\end{tabular}
H.M.C : ハービー・マッド・カレッジ 


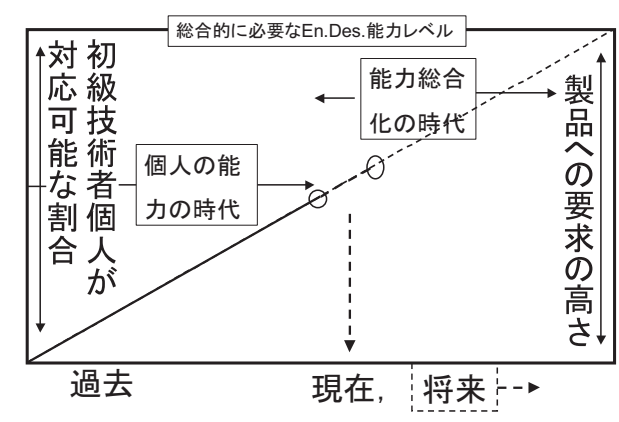

図 5 総合化とグループ活動傾向の次世代ものづくり

表 4 ものづくり経験からの主要教訓概要（初級関係）

\begin{tabular}{|c|c|c|}
\hline 項 目 & 概 & 摘要 \\
\hline \multirow{2}{*}{$\begin{array}{l}\text { 人的 } \\
\text { 要素 }\end{array}$} & R \& D は人材 (情熱, 責任感, 知識 $\cdots$ ) & \\
\hline & 優れたトップと補佐（管理者, スタッフ） & \\
\hline \multirow{4}{*}{$\begin{array}{l}\text { 技術 } \\
\text { 技法 }\end{array}$} & 顧客優先とコミュニケーションの大切さ & \\
\hline & システム分析, Engineering Specialty & \\
\hline & 現場尊重, 製品履歴の保存の必要性 & 記録 \\
\hline & 工程管理の重要性, Mil-STD-499Aの効果 & \\
\hline \multirow{2}{*}{$\begin{array}{c}\text { 管理 } \\
\text { その他 }\end{array}$} & コスト概念の重要性 & \\
\hline & ノウハウのデータ化 & 記録 \\
\hline
\end{tabular}

表 5 創造実験教育からの教訓

\begin{tabular}{|c|l|c|}
\hline 項 目 & \multicolumn{1}{|c|}{ 概 } & 摘要 \\
\hline \multirow{2}{*}{ 人的 } & 動機付けの重要性 & 創造 I \\
\cline { 2 - 3 } 要素 & 達成感を与えることの重要性 & 全般 \\
\hline \multirow{2}{*}{$\begin{array}{l}\text { 教育の } \\
\text { 仕組み }\end{array}$} & 設計者と製作者の独立性確保の重要性 & 創造 III \\
\cline { 2 - 3 } & グループ活動によるものづくりの必要性 & 創造 IV \\
\cline { 2 - 3 } 教育の & ポートフリオ作成は理解に高い効果 & 創造 IV \\
\cline { 2 - 4 } 内容 & 加工技能・基礎・専門知識の重要性 & 全般 \\
\cline { 2 - 4 } & 技術融合教育の必要性 & 全般 \\
\hline
\end{tabular}

級技術者教育が変換点にあることを裏付けている.

表 4 の教訓では, 技術者倫理, コミュニケーション 能力, 読み・書き・計算能力の大切さや,「記録」作業 の重要性を示していると言える。また，現場の技術即 ち,ノウハウや経験が極めて重要であることも意味し ている。

表 5 に，金沢高専の第 3 期ものづくり教育の総括か ら得られた教訓を示す。一連の積み上げ式創造実験教 育体系において, ものづくりで動機づけられた学生が, ものづくりの全体を見通しながら個々の細目で達成感 を感じながら, 成長して行くことが重要であることを 示している．同時に，後述するポートフォリオを用い たノウハウの伝承が効果のあることもわかる.

表 1 と表 5 を比べると, ものづくりの第 3 期当初に おいて心がけた表 1 の要素が, 教員が期待したほど学 生の身についていないことが判る。同時に, 表 3 や図 5 の趨勢を考慮すると, 学生の授業満足度を高めるこ とは出来ても, 時代の要望に対応できる初級技術者の 育成を達成できないことが予想され，教育体系を改善

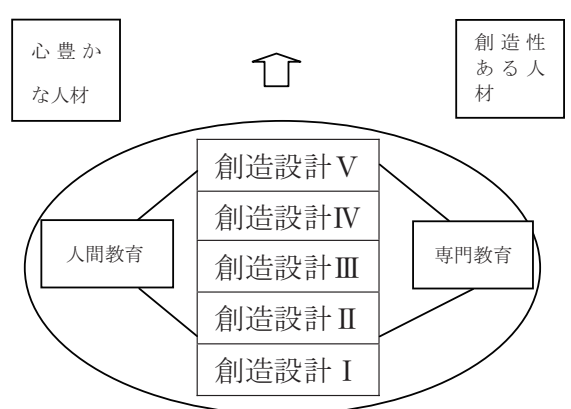

図 6 金沢高専のものづくり主柱の教育体系

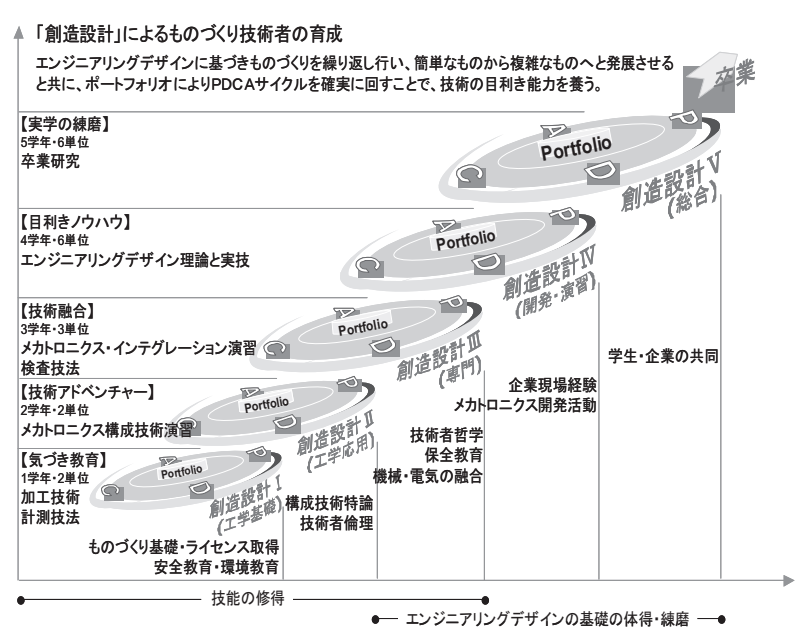

図 7 機械工学科第 4 期ものづくり教育の体系

する必要があることが判った。

\section{2 第 4 期ものづくり教育（教育体系の改善）}

第 4 期のものづくり教育体系では， 2.2 で既述し たように, 学生の育成目標を「ものづくりの過程を通 じ，技術の目利きが出来る実践的技術者の素養を育成 する」，及び育成する技術的資質目標は継承することと し，エンジニアリングデザイン教育の取り达みも含め 技術的にも時代に対応できるものとした. 同時に, 教 育改革で実施中のキャリアデザインや地域企業との連 携教育活動も，ものづくり教育と並列させ連携を図る こととした．改善は全学年同時に実施することとした.

四 6 は，金沢高専の全般教育体系におけるものづく り教育の位置付けを, 図 7 は, 機械工学科の第 4 期の ものづくり教育体系の概要を示している。図 6 では, 金沢高専の教育体系がものづくりを中心として構成さ れており，もうひとつのキャッチフレーズ「ものづく りは人づくり」が, 明確になっていることがうかがえる.

機械工学科の第 4 期ものづくり教育体系は, エンジ ニアリングデザインおよびマネジメント取り込みの思 想を明確化し (図 7 ), 名称を創造実験から創造設計 へと改称すると共に,「16歳からする将来の工場長育 成教育」と具体化する教育体制（表6）となった.

創造設計 I は, 新入生のための「動機付け教育」で ある.ここでは技術者としての心構え, 機械加工や計 測法について実習し，工学の基礎の修得と必要なライ センスを取得すること（図 8 ）を義務づけている. 
表 6 創造設計教育の推進体制

\begin{tabular}{|c|l|c|c|c|}
\hline $\begin{array}{c}\text { 創造設 } \\
\text { 計区分 }\end{array}$ & $\begin{array}{c}\text { 内 容 } \\
\text { 概 }\end{array}$ & $\begin{array}{c}\text { 時間数 } \\
\text { (時限) }\end{array}$ & $\begin{array}{c}\text { 教員数 } \\
+\mathrm{TA} \text { 数 }\end{array}$ & $\begin{array}{c}\text { 学生数 } \\
\text { (名) }\end{array}$ \\
\hline I & 動機付け, 加工 & 60 & $4+0$ & 45 \\
\hline II & 構成技術等 & 60 & $3+0$ & $15 \times 3 \mathrm{GP}$ \\
\hline III & 技術融合 & 90 & $3+3$ & $3 \times 15 \mathrm{GP}$ \\
\hline IV & メカトロ製作 & $180+a$ & $3+2$ & $6 \sim 7 \times 6 \mathrm{GP}$ \\
\hline $\mathrm{V}$ & 卒業研究 & 180 & 8 & $5 \sim 6 /$ 教員 \\
\hline
\end{tabular}
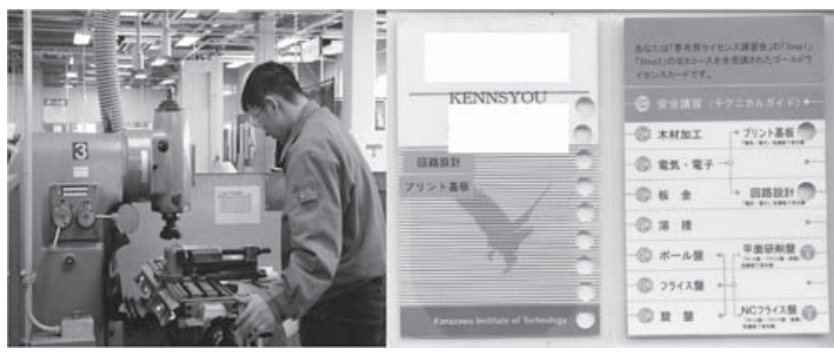

(a) ライセンス講習状況（b）ライセンス取得証明カード

図 8 加工ライセンスの取得例

2 学年の創造設計 II は，技術アドベンチャーと仮称 し，メカトロニクス構成技術を学ぶ工学応用の細目で ある。機構，電源，アクチュエータ，センサ，制御や 信号処理の基礎を理論と実習により学ぶ（図 9 ).

3 学年の創造設計而は, メカトロニクスに関する電 気・電子及び機械技術の統合である，具体的には，マ イコンと自作回路を搭載したライトレースマシンを 2 人 1 グループで設計製作する（図10).

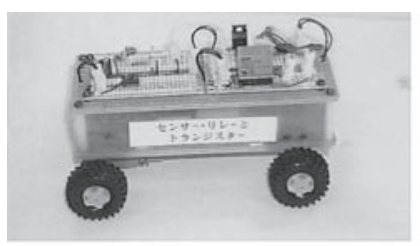

(1)基本部品等主体作品

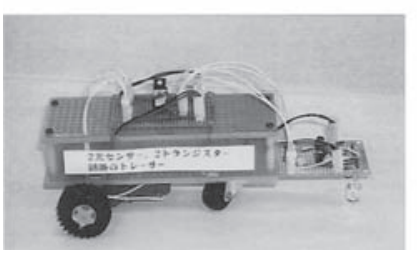

(2) 各種部品応用作品

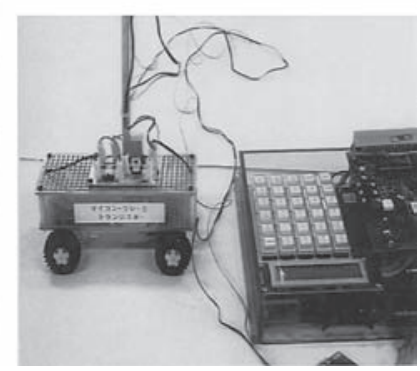

(3)マイコン制御作品

図 9 メカトロニクス基礎技術（II）学生成果物例

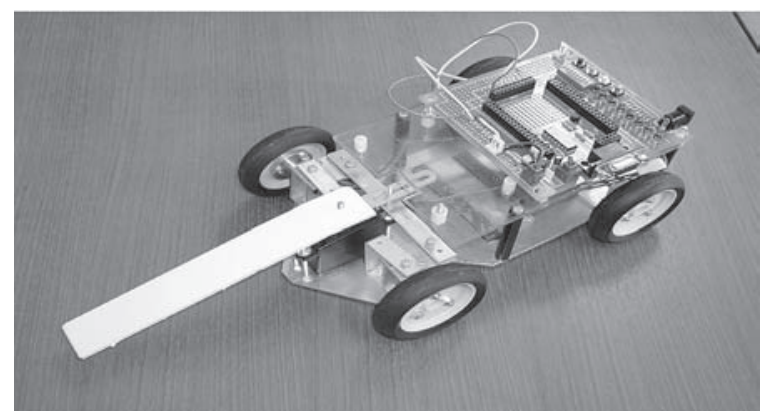

図10 創造設計吕における学生成果物例
創造設計 IV は，積み上げ式メカトロ製作創造設計体 系の仕上げとしての, グループ作業による「校内案内 ロボット」の設計製作である。詳細については 3.3 においてのべる.

創造設計 $\mathrm{V}$ は, 卒業研究である。地域企業と連携し た研究テーマも取りこみ, 個人あるいはグループで研 究を行う。また, 異なる学科の学生がグループを組む 学科横断型の卒業研究 (例: 環境問題) もおこなう.

\section{3 創造設計IVの詳細}

創造設計IV は，エンジニアリングデザイン，エンジ ニアリング・マネジメント技法を適用し，ものづくり 教育の仕上げ段階である.

本細目では，エンジニアリングデザイン，エンジニ アリングマネジメントの意味として，図11のように包 括的に捉えている，2.2のように，MOT教育の必要 性は認めるものの, 細部理論については就業後のOJT や自己努力に期待し，創造実験IVでは，これらを熟練 者のノウハウとして受け止め, 体験的に扱う.

図12に，創造設計 $\mathrm{IV}$ を実施する教育実施方針の要旨 を示す。この細目が「単なる製品製作に終始するもの づくり」と明確に区別されていることが判る.

図13に創造設計 IVの具体的テーマを，戝14に指導の 流れを, 眓15にシステム設計体系の基準を示す。

学生は, 図13の制限の範囲内で, 自由な発想の下に

1. 製品化に必要なエンジニアリングデザイン実務実施 の工学手法と加工技術

2. エンジニアリングデザインの科学的管理概念

3. 法規や社会通念等に基づく業務処理の概念

図11 エンジニアリングデザインの意味

1.グループ作業により，基本的なメカトロ機材の創造 製作を行う（MIL-STD-499Aを準用する.）

2. 顧客要求分析を基に, アイディア創出〜製品製作ま でを，想定方式により段階的な問題を付与し，学生 主体で要求解決のための自主製作を行う.

3. ロールプレイ,技術審査（発表・討議・評価・結論導出） 並びに，ポートフォリオ方式による記録とその管理 を行う。

4.グループのデータ管理及び価格管理を行う.

5. 企業技術者の教育参加と対応のインターンシップを 行う.

6. 成績評価は, 個人評価, 相互評価, グループ評価を 総合する.

図12 創造設計IVの方針要旨

1. 製作物：基礎的な自律型校内案内ロボット

2 . 制約条件

(1)大きさ： $1200 \mathrm{mmH} \times 1000 \mathrm{~mm} \times 1000 \mathrm{~mm}$ 以内

(2)動作：玄関から事務室まで訪問者を案内出来る電動式

(3) 機能 : 音声案内, 案内用パーフォーマンス 2 種以上

(4) デザイン：自由, 内部機構が見えるスケルトンタイプ

(5)安全性：小学生以上の取り扱いで安全なこと

(6)その他：価格10万円以下, キャラクター性

図13 創造設計 IV の製作課題 
(前期)

1.エンジニアリングデザイン概論, システム工学概論

2. 既製品評価, 評価会議, 教訓事項の学習・記録

3. 顧客要求分析, 運用要求・要求性能, システム解析, 技術審査

4. 工事計画作成, 概念設計, 組み立て図, 技術審査

5 . 細部設計, 製図, 技術審査

6. モックアップ製作・発表，技術審査

7. 製作資材要求説明, 予算説明, 発注作業, 発注

8.ロボット製作, 資材・部品等領収検査 (後期)

9. 製作活動, 製作中間報告, 技術審査

10. 主要部の関連試験（グループごと）, 技術審査

11. 組み立て, 調整, 専門工学活動, 作動試験

12. 性能確認試験（成績評価試験を兼ねる）

13. 最終報告会

14. グループ報告書提出, 個人レポート提出

図14 創造設計 IV の作業指導要領（シラバス）概要

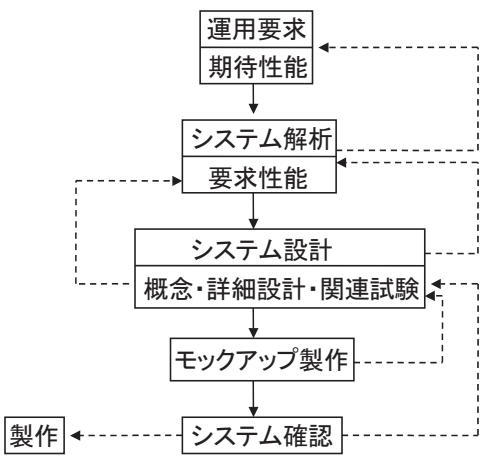

図15 システム設計体系の基準 (Five Stage Model ${ }^{4)}$ )

校内案内ロボットを創造・設計・製作する．アイディア 創出の段階では，ブレーンストーミング法を活用する.

創造設計 IV の特徵は，教育が「ものづくりの流れ」 の中で行われることである，教員は，図14の流れに則 ったシラバスを作成する。各項目（細目）の実施に配 分する時間数は, 創造設計 I 〜 III までの教育経験に基 づいて決定している，個々の細目を開始する際には, 後述の想定方式で問題を付与し, これを解決するため の活動に取り組むという動機付けを行う。

ものづくりのためのシステム設計体系には，多くの 手法がある。本教育では, 図15に示した設計体系に 従い教育を進めている。この体系は，一般にはFive Stage Model ${ }^{4)}$ と呼ばれている.

図において, 運用要求は顧客（あるいは営業側）要 求を, 期待性能は運用要求を数值目標化, システム解 析は代替案を含む製作方針と概要，要求性能は期待性 能を技術的な側面から可能性を含んで表現したもの及 び，関連試験とはシステム構成に係わる技術的可能性 を検討することを意味している.

\section{4. 教育実施について}

創造設計 IV では第 3 期教育体系以降，幾つかの新し い試みを実施している。

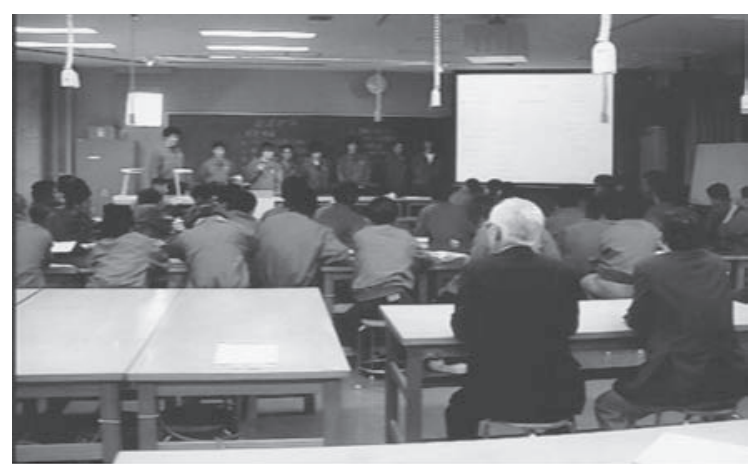

図16 技術審査状況例

\section{〔技術審查〕}

技術審査の目的は，ものづくりが計画通り実施でき るかどうかを，技術的な見地から妥当性を審査するも のである. 妥当性の評価事項は審査を実施する課題に よって異なるが, 原則的には, 考え方, 適用技術, 設 計計算, 使用材料, 試験結果, 改善方法およびその効 果, 完成品の状況等を基準に具体化することになる.

本教育に扔ける技術審査風景例を図16に示す。図16 の技術審査例は, 校内案内ロボットの概念設計が終了 した段階のものである.グループ構成員全員が演壇上 に立ち, 司会者（教員）の司会の下に, パワーポイン トを使用しグループ長が全般及び設計方針を, 続いて グループの担当員を勤める学生が, 機構, 電源・動力, 制御・センサ等の設計概要, 組み立て図等について説 明する. 他の学生は, 技術審查側の専門技術員となり, 連携企業の技術者や教員と共に質問し, 状況によって は誤りある説明箇所の修正を要求する。この際, 説明 側の学生の態度や参画状態に指導を要する場合や, 発 言が極度に少ない学生については, 教員が指導的見地 で個人的に指導質問をする。技術審査結果については, 修正方法も含め，後日の授業で処置をする。

図16の後尾の 2 名は, 会議を見学中の第 3 者（一般 人）である.

\section{〔ポートフォリオ}

本教育におけるポートフォリオは, 知識と教訓に関 する資料集と位置づけている，特に熟練者から学習す るノウハウに関する聞き取り筆記については, 就業後 に役立つことから，キャリアデザインにも関連すると して, 特に重視している. 図17に, 創造実験 $\mathrm{IV} て ゙$ 学生 が作成したポートフォリオの例を示す．図17のポート フォリオ例は, 制御系の概念設計が終了し, 技術審査 前に指導教員の点検を受ける時期のものである. 図 17 の右図の学生の場合, 添付書類としてCADで書いた ロボット作動ブロック線図がある.

学生は，1日の教育が終了後にポートフォリオを提 出する. 課外時間に作業する学生については, 課外作 業で実施した内容と費やした実時間を闌外に併記し， 作業終了の翌日授業開始前にこれを教員に提出する. 受領した教員は努めて速くポートフォリオを点検・検 


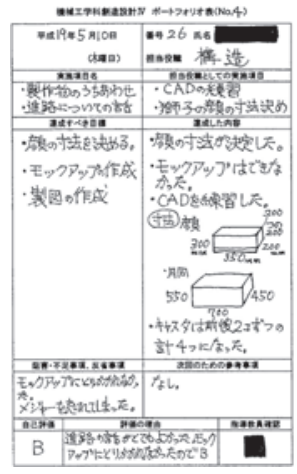

(a) A学生作成

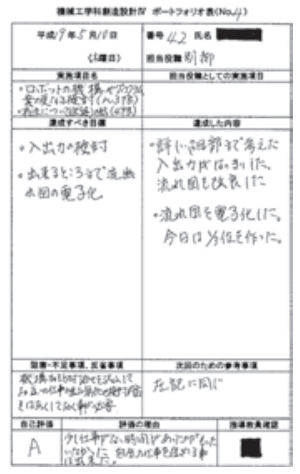

(b) B学生作成
図17 ポートフォリオの例

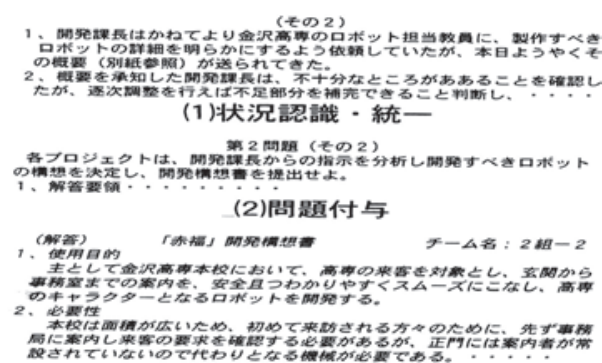

(3) 回答例

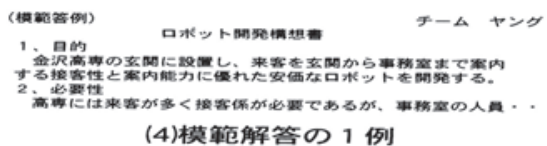

(4)模範解答の 1 例

図18 想定方式による問題付与例

印し，必要な場合はコメントを朱書きしたのち学生に 返却する。同時に，ポートフォリオ中に積極的な学生 提案や，チームティーチング中の他の教員と調整する 必要がある事項を認めた場合には，教員調整会議を開 催し次回授業までに処置する。学生は受領したポート フォリオを，別にキャリアデザイン活動で作成してい るキャリアポートフォリオと関連させてファイルに保 存する.

〔想定方式による問題付与〕

図18は，想定方式 ${ }^{5)}$ の状況付与等の例である. 教 育の進度はシラバスで規制するが，教育目標を達成す るためには，計画した時間内に学生作業を終了させる 必要がある。ものづくり教育の場合，時間内に完成し た範囲で可としがちである。ところが納期感覚を体得 させるためには，決められた作業時間内で教育目標を 達成する必要がある.グループ作業の場合には, グルー プをミニ企業とし学生が企業内役職を分担するため, 学生個々の作業量に差が生じることとなる，学校教育 では，ものづくり過程で作業量に差が生じることや， 決心する事項に関する責任が特定の個人に偏ることを 避ける必要がある。 そこで，作業の重要な事項の場合 にはグループ活動を一時中止し，意図的に仮想の状態 （例えば，各学生を技術課長とする）に抄き，決心事 項を課題として学生全員に付与する。これにより，学 生は従事者並びに，管理者の立場で決定行動を体験し 知識を修得できる。また，この想定方式がロールプレ

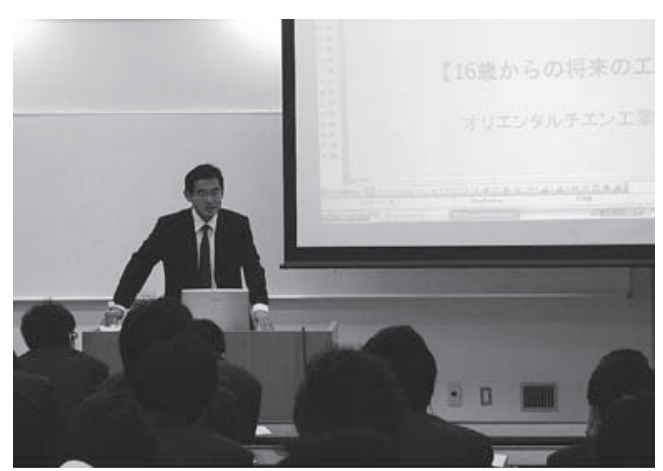

図19 企業技術者の講演（創造設計 II ）

\section{イにも繋がってゆく.}

〔専門工学活動 (Engineering Specialty)]

MOTでは, 工学的な判断基準を物理理論やシステ 厶工学, 安全性工学, 人間工学, 電磁適合性工学, 価 值工学理論に基づいて実施する. MIL-DTD-499Aで は, 類似の更に詳細な専門工学的活動がある. 熟練技 術者のノウハウに近いこれらの項目は, 信頼性工学, 整備性工学, 工学倫理等も含んでいる. 企業の技術者 のノウハウの多くはこれらの項目を含んでいるので, ベテラン技術者の講話は特に効果がある（図19）。

〔ロールプレイ〕

グループによる製作活動が㤢性に流れないため, グ ループを企業として設想し, 学生個々を役職者及びそ の部下に指名する。 区分は課長, 班長及び班員である. この役割分担は教員が指定し，その後，教育的目的を もって年 3 回程度交代する。 また, 企業の技術者の臨 席で実施するロールプレイの会議や検討会は, 実社会 でのものづくりの厳しさを直に体験でき，きわめて教 育効果がある.

\section{〔グループ構成〕}

グループ構成員の組み合わせは，本教育の重要事項 の一つである。教育進度をほほ均一にするため, 各グ ループの能力差を付けないことが必要である. 学生の 選定方法には，同好者による構成，学生名簿番号によ る構成, 成績序列に基づくグループ学業成績均等構成 及びランダム選択による構成などがある。第 3 期の教 訓から，ランダム選択したグループ構成が妥当である ことを確認している.

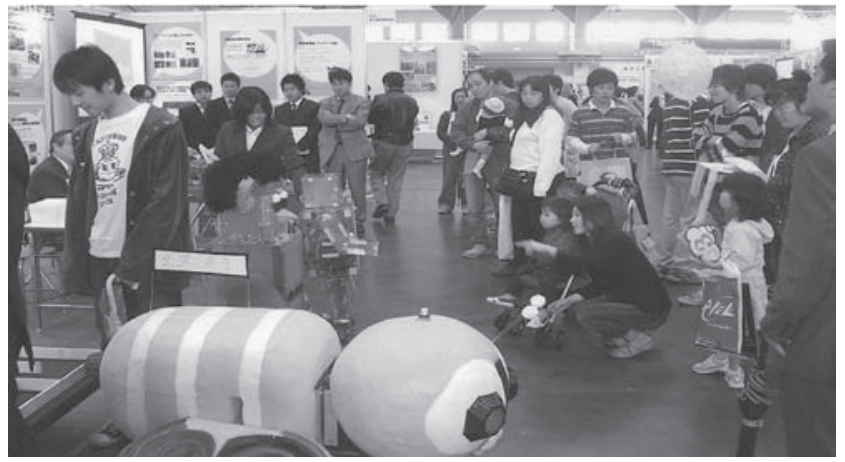

眓20 見本市に出展の学生成果物 


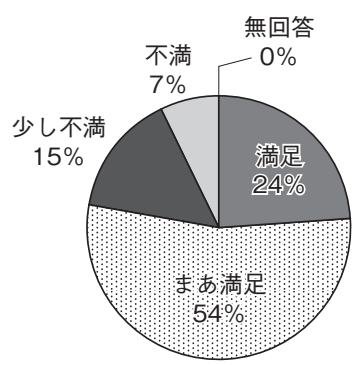

(a) 2006年度

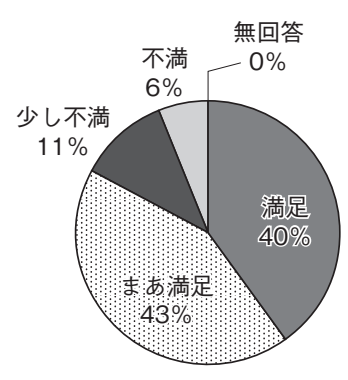

（b）2007年度
図21 授業満足度に関するアンケート中間調査結果

\section{〔学生の成果物〕}

学生の成果物のうち $2 \sim 3$ 点は, 毎年 5 月に行われ る石川工業見本市に, 総ての作品は10月に開催される 学園祭で展示され, 第 3 者の評価を受けている. 学生 はこの展示で, 耐久性, 安全性, 整備性などの重要性 を認識することとなる（図20）。

\section{〔成績評価〕}

創造実験 $\mathrm{V}$ における成績評価は，課題やレポート結 果の個人評価, 平常点, グループ作業における相互評 価及び作品の適切性によって, 総合的に行う. 相互評 価は協調性, 問題解決貢献度, 出席状況, 及び態度の 4 項目について 5 段階評価をする. グループ内順位付 けを実施し，規定の比率で総合成績に加算する.

作品の適切性は, 最も重視する項目である。評価日 時をあらかじめ指定した上で, 作品の運用要求が実現 されたかどうかについて評価される。この際, 不可動 などの不適合事項があれば，再評価を実施する，万一 再評価時点でも不合格になれば, 単位は与えられない。

\section{5. 教育結果}

図21に，第 4 期の創造設計 IV に関する学生の授業満 足度のアンケート結果を, 第 3 期末のそれと対比し示 す．校内案内ロボットの製作は課外時間等も活用する 場合があるものの, 授業満足度は第 3 期末の年度のそ れに比べ高い.このことは, 創造設計の各段階におけ る教育内容が改善されたこと, ものづくりの達成感が 増したことのほか企業連携や講演等が加わり，グルー プ活動の内容が深まった効果の現れである. 自由記述 式のアンケート結果, ポートフォリオ及びものづくり に関するヒヤリングなどからも，同様な結果が得られ ている.

一方, 不満足の理由には, 授業進度が速い, 課外作 業がある，ロールプレイで役職を交代すると申し送り が難しいなどが上がっている.

\section{6. 今後の課題}

本教育は, 学生の満足度が高いものの, 担当教員の 負担が大きいという指摘がある. 特にポートフォリオ のコメント作成と, 課外時間における教育支援である. また, 担当教員チームは, 学生の各種の質問に回答で
きる知識と正確な加工能力とが必要である. 現在, こ の分野に企業技術者の協力が得られており，より良い 成果を期待できる。 また, 企業経験者の協力により学 生の自律と安全意識が高揚している. なお, 技能面で は教員数の増加のみでは対策できないので, 地域企業 と恒久的に連携し, ベテラン技術者の講義への参画や 技能指導の導入など, 新たな施策も推進している.

本教育方式における全般的留意事項は, 指導側や学 生がものづくり結果の出来栄えにのみ固執しないこと である. 第 4 段階の教育体制に入って以降の学生成果 物の出来栄えは, 以前のそれと比較して格段の進歩が 認められる. 運用要求に合った成果物を作ること, ポー トフォリオを完成すること拉よび, エンジニアリング デザインとマネジメントの両方の概念を教育すること の， 3 者を追及することが肝要である.

\section{7. むすび}

実社会及び教育教訓に基づき,「実学」的内容を加 味した創造設計教育体系は, 学生の授業満足度も高く 有意義である. 特に, 総括的なエンジニアリングデザ インの思想を組み入れた創造設計 IV は, 学生の満足度 も高く, 地域企業に就職する高専生にとっては好まし いものづくり教育と言える.

なお, 本教育は, 2007年度の文部科学省の, 産学連 携による実践型人材育成事業に採択されている.

\section{参 考 文 献}

1) 林 利弘：モノ・コトづくりを強くするもう $1 つ$ のMOT, \#1ワークショップ, 日本工学教育協会シ ンポジウム, 2007. 3

2 ）堀岡, 山田：金沢高専における創造教育の現状と 展望, 工学教育, $51-1$, pp.16-23, 2003

3 ) 科学技術部会: システム装備の研究開発管理, 陸 戦研究, 1994年 7 月号, pp. $51-61,1994$

4) Dym\&Little : Engineering Design, Wiley, U.S.A, 26, 1998

5 ）山田, 竜野：創造設計教育方に関する 1 考察－想 定方式の導入 - , 日本工学教育協会平成14年度年 次大会講演論文集, pp. $81-82,2002$

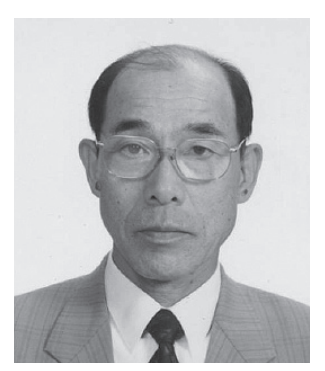

\section{著者紹介}

\section{山田 弘文}

昭和15年 4 月生まれ 昭和 38 年 3 月防衛大学校卒 昭和 45 年防衛大学校理工学研究科卒 陸上自衛隊, 防衛庁技本, 陸上幹部学校 平成 7 年金沢高専機械工学科教授 平成18年金沢高専校長 工博, 専門は精密加工, システム工学 日本工学教育協会, 精密工学会, 先端加 工学会, 特別教育士 